\title{
Amino Acid Substitution and Chemical Characterization of a Japanese Variant of Carbonic Anhydrase I: CA I Hiroshima-1 (86 Asp $\rightarrow$ Gly)
}

\author{
Takeshi Kageoka, ${ }^{1,2}$ David Hewett-Emmett, ${ }^{1}$ Sharon K. Stroup, ${ }^{1}$ Ya-Shiou L. \\ Yu, ${ }^{1}$ and Richard E. Tashian ${ }^{1,3}$
}

Received 25 June 1980-Final 15 Oct. 1980

An electrophoretic variant of red cell carbonic anhydrase I, designated CA I Hiroshima-1, has been observed in 12 apparently unrelated individuals during a survey of 13,019 individuals from the cities of Hiroshima and Nagasaki, Japan. Analyses of tryptic and chymotryptic peptide patterns of this $C A$ I variant purified from 8 of the 12 individuals revealed the same altered peptides in each case. Examination of the amino acid sequence of an altered tryptic peptide purified from one of the variants showed that the aspartic acid residue at position 86 was replaced by a glycine residue. Thermostability studies demonstrated that all samples of CA I Hiroshima-I were less stable than normal $C A I$. The specific esterase (p-nitrophenyl acetate) activities of the normal and variant $C A I$ isozymes were essentially the same. The difference spectra of the normal and variant enzymes were essentially the same. The isoelectric focusing patterns of CA I Hiroshima-1 showed a different pattern of minor bands to those produced by normal $C A$ I. The relative amounts of the normal and variant enzymes purified from single heterozygous individuals were similar.

KEY WORDS: Carbonic anhydrase I; human variant; thermostability; isoelectric focusing; back mutation.

This work was supported by U.S. Public Health Service grant GM-24681 and U.S. Department of Energy contract 2828 (to Dr. J. V. Neel).

${ }^{1}$ Department of Human Genetics, University of Michigan Medical School, Ann Arbor, MI 48109.

${ }^{2}$ Present address: Department of Internal Medicine, University of Tokyo Medical School, Tokyo, Japan.

${ }^{3}$ Author to whom reprint requests should be sent. 


\section{INTRODUCTION}

Three isozymes of carbonic anhydrase (termed CA I, CA II, and CA III), which are under the control of three separate genetic loci, have now been characterized from human tissues; and their chemical properties, structures, tissue distribution, genetic control, and evolution have been the subjects of several papers and reviews (cf. Lindskog et al., 1971; Carter, 1972; Tashian and Carter, 1976; Tashian, 1977; Pocker and Sarkanen, 1978; Carter et al., 1979; Tashian et al., 1980a,b,c).

At least 20 electrophoretic variants of CA I, and seven electrophoretic variants of CA II, have now been discovered in the hemolysates of individuals from a wide variety of ethnic groups. The amino acid substitutions have been determined for seven of the CA I variants and one of the CA II variants (for a review, see Tashian et al., 1980c). As yet, no variant of human CA III (found mainly in red skeletal muscle) has been detected (Carter et al., 1979; Hewett-Emmett and Tashian, 1979).

An electrophoretic variant of red cell CA I, originally designated CA Ih Hiroshima, was first reported by Ueda (1974) in two individuals from Hiroshima, Japan, and subsequently two more individuals from Hiroshima were found with what appeared to be the same variant (Ueda et al., 1977). In this report, we have designated the variant, CA I Hiroshima-1 (abbreviation: CA I HIR-1), in keeping with the nomenclature suggested by Tashian et al. $(1980 c)$. A preliminary chemical characterization of this variant was reported by Tanis et al. (1976); however, the amino acid substitution was not determined. During a more recent electrophoretic typing survey of red cell CA I and CA II carried out on individuals residing in Hiroshima and Nagasaki, seven additional examples of what seemed to be the CA I HIR-1 variant were discovered from Hiroshima and one from Nagasaki.

In the present report, we describe the amino acid substitution and some chemical properties of CA I Hiroshima-1. In addition, an attempt is made, utilizing peptide mapping techniques, to determine whether each of eight available samples of this variant from different individuals represent the same substitution.

\section{MATERIALS AND METHODS}

\section{Isolation of the Variant Enzymes}

About $50 \mathrm{ml}$ of whole blood was obtained from eight individuals who were heterozygous for CA I HIR-1. Whole blood was collected in acid-citratedextrose (ACD), washed three times with $0.85 \% \mathrm{NaCl}$, and stored at $-70^{\circ} \mathrm{C}$. Normal outdated bloods were obtained from the University of Michigan Blood Bank. 
Purification of the variant enzymes was carried out using affinity chromatography on sulfonamide-bound CM-Sephadex columns by the method of Osborne and Tashian (1975). Further purification was achieved on a DEAE cellulose column (Whatman DE-32, $1 \times 80 \mathrm{~cm}$ ) equilibrated with $0.025 \mathrm{M}$ Tris- $\mathrm{HCl}, p \mathrm{H}$ 8.7. CA I HIR-1 and normal CA I were then successively eluted with a linear $0-0.2 \mathrm{M} \mathrm{NaCl}$ gradient.

\section{Electrophoresis and Isoelectric Focusing}

Starch gel electrophoresis was carried out using a borate buffer system at $p \mathrm{H}$ 8.6, as previously described (Tashian and Carter, 1976). During the survey, the esterase activities of CA I and CA II after electrophoresis were detected with 4-methyl umbelliferyl acetate for CA $I$ and fluorescein diacetate for CA II (Hopkinson et al., 1974).

Polyacrylamide slab gel electrophoresis was carried out as previously described (King and Laemmli, 1971), and stained with a $0.3 \%$ solution of Coomassie Brilliant Blue R-250. SDS polyacrylamide gel electrophoresis was carried out essentially as described by Laemmli and Favre (1973).

For the isoelectric focusing in polyacrylamide gel, $75 \mu \mathrm{g}$ of purified normal or variant CA I was applied to an LKB Ampholine PAG plate $(p H$ range 5.5-8.5), and run for $2.5 \mathrm{hr}$ at $10^{\circ} \mathrm{C}$ with an LKB Multiphor power supply.

\section{Analysis of Peptide Patterns}

Peptide mapping techniques following trypsin and chymotrypsin digestion were performed as described by Tashian et al. (1966). Four milligrams of normal or variant CA I was denatured at $95^{\circ} \mathrm{C}$ for $3 \mathrm{~min}$ in $0.2 \mathrm{M}$ ammonium

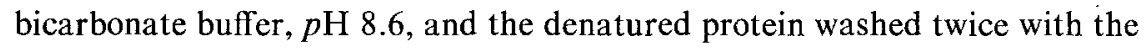
same buffer. The precipitate was digested with trypsin $(2 \% \mathrm{w} / \mathrm{v})$ for $90 \mathrm{~min}$ at $37^{\circ} \mathrm{C}$. The digest was then centrifuged for $5 \mathrm{~min}$ at $3000 \mathrm{rpm}$ to separate the undigested "core," and the supernatant was applied to Whatman 3 MM filter paper sheets. After descending chromatography in butanol-acetic acid$\mathrm{H}_{2} \mathrm{O}$ (38:9:45), electrophoresis was performed at $2000 \mathrm{~V}(120-140 \mathrm{~mA})$ for $80 \mathrm{~min}$ in pyridine-acetic acid- $\mathrm{H}_{2} \mathrm{O}(25: 1: 225), p \mathrm{H} \mathrm{6.4}$, or in formic acidacetic acid- $\mathrm{H}_{2} \mathrm{O}$ (25:87:888), $p \mathrm{H}$ 2.0. After drying, the filter paper sheets were sprayed with a cadmium-ninhydrin staining solution (Heilmann et al., 1957). The tryptic "core" was washed twice with $0.2 \mathrm{M}$ ammonium bicarbonate buffer, $p \mathrm{H} 8.6$, and digested with chymotrypsin (1\% w/v), followed by descending chromatography and electrophoresis in the $p \mathrm{H} 6.4$ buffer. 


\section{Amino Acid Sequencing}

About $10 \mathrm{mg}$ of normal or variant heat denatured CA I was digested with trypsin $(2 \% \mathrm{w} / \mathrm{w})$ for $12 \mathrm{hr}$ at $37^{\circ} \mathrm{C}$ to obtain the altered, and corresponding normal, ninhydrin-free peptides for sequence analysis. The soluble tryptic peptides were first separated as described in the preceding section, and the desired peptides were located with cadmium-ninhydrin stained guide strips and eluted with $10 \%$ acetic acid. The eluted peptides were further purified by high voltage paper electrophoresis $(p \mathrm{H} 2.0,2000 \mathrm{~V}, 80 \mathrm{~min})$, and the peptides were located and eluted as above. The purified peptides were then sequenced in a Beckman Model 890B sequencer. The PTH amino acid steps from the sequencer were identified using a high performance liquid chromatography (HPLC) system, which consisted of a Merck RP-18 (10 $\mu \mathrm{m}$ particle size) reverse phase silica column $(250 \times 4.6 \mathrm{~mm})$, an LDC UV II detector $(264$ $\mathrm{nm}$ ), and an Altex model $110 \mathrm{~A}$ pump. Elution of the PTH-amino acids was isocratic, using $40 \%$ acetonitrile $/ 60 \% 0.01 \mathrm{M}$ sodium acetate, $p \mathrm{H} 4.7$, which is similar to the method used by Zimmerman et al. (1977).

\section{Enzyme Assays}

The esterase activity of the normal and variant CA I isozymes was measured by following the increase in absorbance at $348 \mathrm{~nm}$ as described by Armstrong et al. (1966), with $p$-nitrophenyl acetate as substrate.

\section{Thermal Stability}

In order to obtain suitable esterase activity toward $p$-nitrophenyl acetate in the assay system, purified normal CA I and CA I HIR-1 were diluted in $0.1 \mathrm{M}$

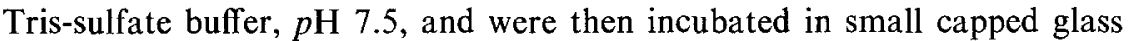
tubes in a thermostatically controlled water bath at $57^{\circ} \mathrm{C}$. At various time intervals, $10 \mu \mathrm{l}$ aliquots were transferred to ice cooled polypropylene microtubes containing $50 \mu \mathrm{l}$ of $0.01 \mathrm{M}$ diethylmalonate buffer, $p \mathrm{H} \mathrm{8.0.} \mathrm{The} \mathrm{tubes}$ were then vibrated on a vortex mixer, centrifuged at $15,000 \mathrm{rpm}$ for $5 \mathrm{~min}$, and $50 \mu \mathrm{l}$ of the supernatant was used for the esterase assay.

\section{Difference Spectra}

The difference spectra, between free and Neoprontosil-bound enzymes, were determined as previously described (Osborne and Tashian, 1974) using a Beckman Acta II recording spectrophotometer equipped with a flat-bed recorder at $25^{\circ} \mathrm{C}$. 


\section{RESULTS}

\section{The Survey}

During the course of a screening program carried out by the Radiation Effects Research Foundation, Hiroshima, on offspring of individuals exposed to atomic bomb radiation, eight individuals (seven from Hiroshima and one from Nagasaki) were discovered who were heterozygous for what appeared to be the same CA I HIR-1 variant in an overall sample of 9,140 individuals from Hiroshima and Nagasaki, Japan. Previously, four individuals (all from Hiroshima) were found with the CA I HIR-1 variant in a sample of 3,969 individuals from Hiroshima and Nagasaki (Ueda, 1974; Ueda et al., 1977). Thus a total of 12 individuals, with no history of a common ancestor extending back two to three generations, have been found who are heterozygous for what is supposedly the same CA I HIR-1 variant in an overall sample of 13,019 individuals from Hiroshima $(7,523)$ and Nagasaki $(5,496)$.

In the present study, $50 \mathrm{ml}$ of whole blood was drawn from eight individuals with the CA I HIR-1 variant. The parents were available for testing for six of these individuals, and in each case, one of the parents was heterozygous for the variant, indicating that the mutation was unrelated to the radiation history. No family study was undertaken for the other two individuals. One of the eight individuals was from Nagasaki, and one of the remaining seven from Hiroshima was the same individual studied by Tanis $e t$ al. (1976).

\section{Purification}

The variant carbonic anhydrases were isolated from the hemolysates of the eight individuals who were heterozygous for the variant. A typical elution pattern after separation on DEAE-cellulose is shown in Fig. 1. As can be seen, the relative amounts of the normal and variant enzymes appear to be about the same.

\section{Electrophoresis}

The electrophoretic patterns of normal CA I and CA I HIR-1 in polyacrylamide gels with and without SDS are shown in Fig. 2A,B. The starch gel electrophoretic pattern of CA I HIR-1 after each isolation step is shown in Fig. 2C. No minor bands were observed, indicating that the enzymes were homogeneous by these criteria. 


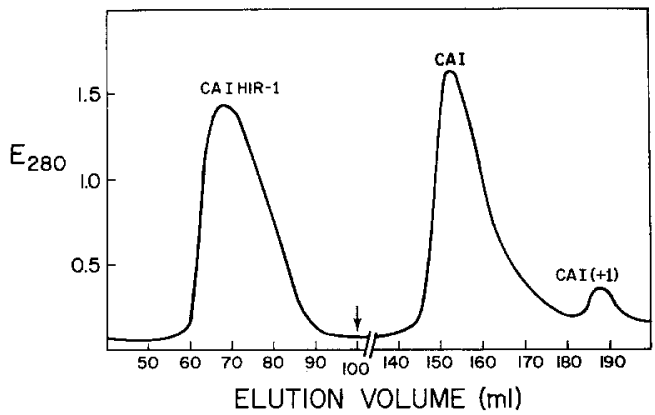

Fig. 1. Elution profile of normal $\mathrm{CA}$ I; the secondary isozyme of CA I, CA I (+1); and CA I HIR-1 (see lane 4, Fig. 2C) after chromatography on DEAE cellulose. Column, $1 \times 90 \mathrm{~cm}$; flow rate, $10 \mathrm{ml} / \mathrm{hr}$; elution buffer, $0.025 \mathrm{M}$ Tris- $\mathrm{HCl}, p \mathrm{H} 8.7$.

\section{Isoelectric Focusing}

The isoelectric focusing patterns of normal CA I and CA I HIR-1 are shown in Fig. 3. Two samples of CA I HIR-1, one from Hiroshima and the other from Nagasaki, exhibit the same patterns of major and minor bands and these in turn are different from the pattern of normal CA I. It appears that the amino acid replacement in CA I HIR-1 results in the production of secondary bands whose patterns differ from those of the normal enzyme. The isoelectric points of the major bands of CA I and CA I HIR-1 were estimated from the $p \mathrm{H}$ curve of the isoelectric focusing gel, and these were 6.33 and 6.87, respectively.

\section{Peptide Analyses}

Tryptic peptide patterns (two-dimensional) were prepared from the CA I variants which had been purified from the hemolysates of the eight individuals with the CA I HIR-1 variant.

In each of the eight variant tryptic peptide patterns, a yellow-staining peptide that is normally present in the neutral region of the pattern from normal CA I was found to have shifted toward the cathode. A typical pattern is shown in Fig. 4A. Assuming the altered yellow peptide differed from the normal yellow peptide by a charge of +1 , and since the peptide exhibited a migration ratio of 0.27 relative to aspartic acid, it was estimated to have a molecular weight of about 1000 (Offord, 1966).

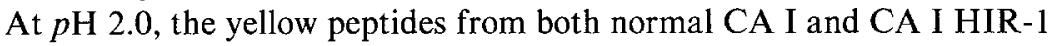
migrate to similar positions on their respective peptide patterns, but are well 
A B
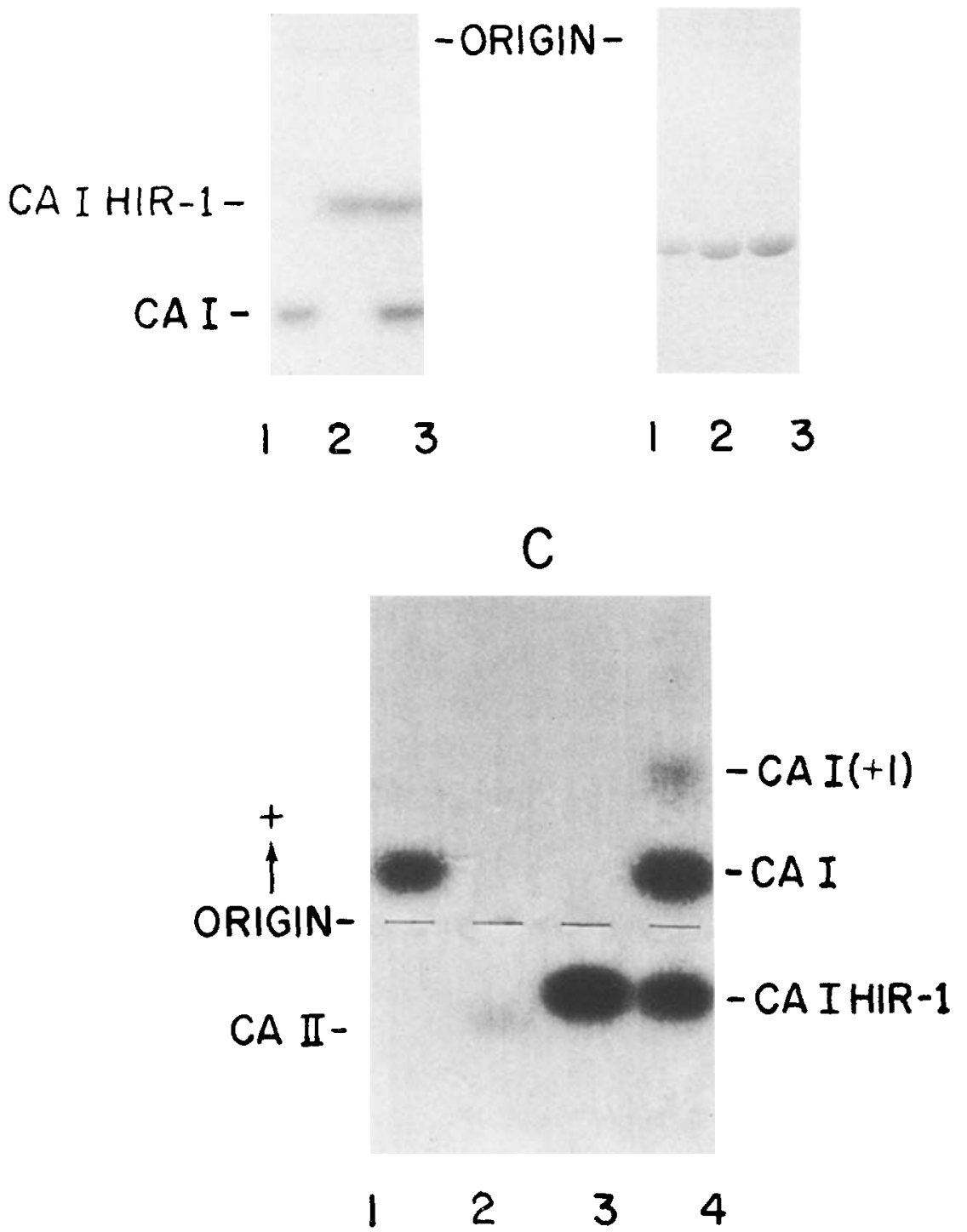

Fig. 2. (A and B) Protein stained (Coomassie blue) patterns of normal CA I and CA I HIR-1 after electrophoresis in polyacrylamide gels in the absence (A) and presence (B) of $0.1 \%$ SDS. Lanes 1, 2, and 3 are, respectively, CA I, CA I HIR-1, and a mixture of CA I and CA I HIR-1. Electrophoresis carried out at room temperature for $5 \mathrm{hr}$ in $12.5 \%$ acrylamide (separating gel) containing $0.375 \mathrm{M}$ Tris- $\mathrm{HCl}$ buffer, $p \mathrm{H} 8.8$; stacking gel ( $5 \%$ acrylamide) made up in $0.125 \mathrm{M}$ Tris-HCl buffer, $p H$ 6.8. (C) Starch gel electrophoresis protein patterns (Nigrosin stain) of CA I, CA I (+1), CA II, and CA I HIR-1 after different isolation steps. Lane 1, CA I after affinity and DEAE chromatography; lane 2, CA II after affinity chromatography (included as a migration reference for CA I HIR-1); lane 3, CA I HIR-1 after affinity and DEAE chromatography; and lane 4, CA I, CA I $(+1)$, and CA I HIR-I pool from affinity chromatography (see Fig. 1 for source of material after DEAE separation). Vertical starch gel electrophoresis carried out in $0.02 \mathrm{M}$ borate buffer, $p \mathrm{H} 8.6$, at $4^{\circ} \mathrm{C}$ for $17 \mathrm{hr}$ at $8 \mathrm{~V} / \mathrm{cm}$. 


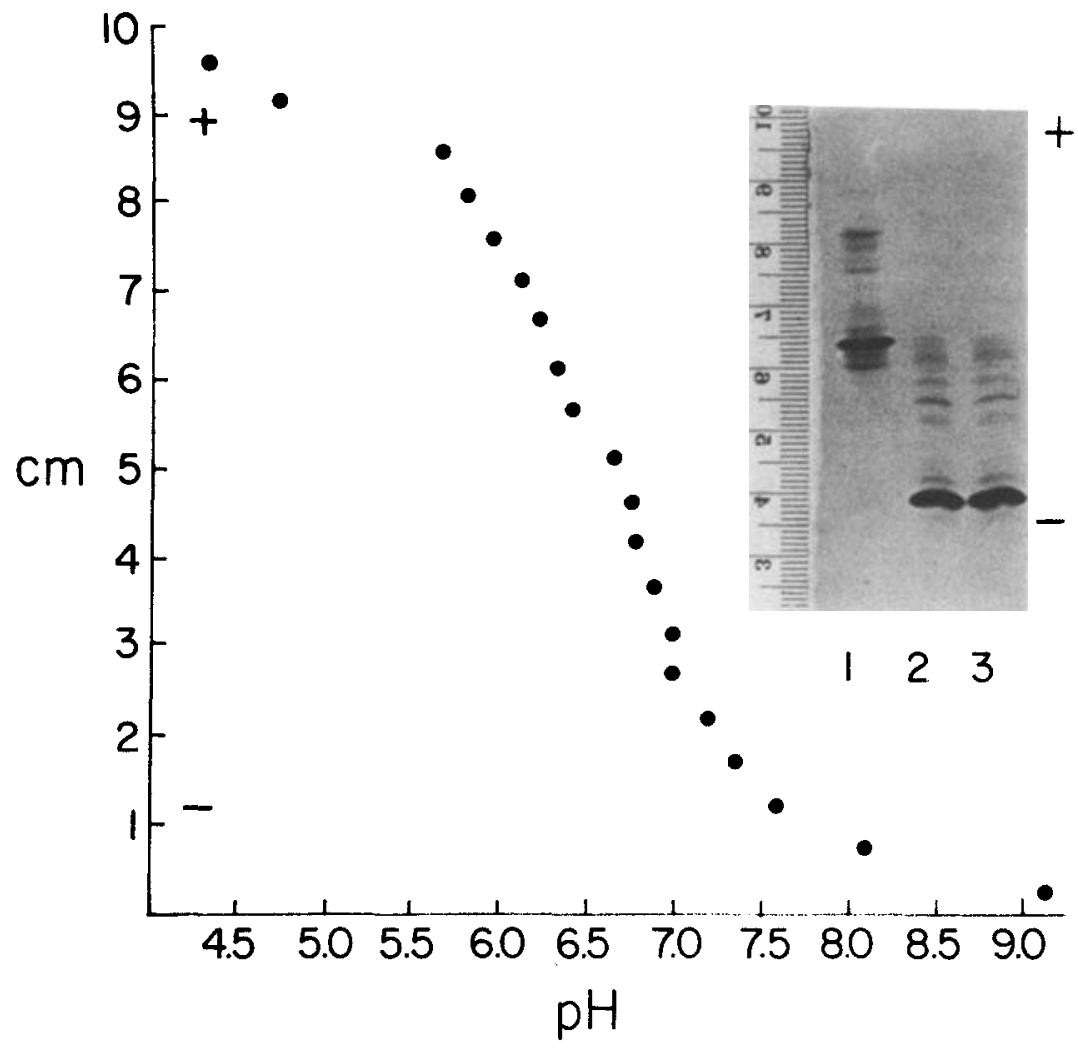

Fig. 3. Isoelectric focusing patterns of normal CA I and CA I HIR-1. Lane 1, CA I; lane 2, CA I HIR-1 from Hiroshima; and lane 3, CA I HIR-1 from Nagasaki.

separated from surrounding peptides. Because of this convenient separation, electrophoresis was carried out at $p \mathrm{H} 2.0$ in order to isolate the normal and altered tryptic peptides for further analyses.

Comparisons of the chymotryptic peptide patterns from CA I HIR-1 and normal CA I show that an anodally migrating peptide in normal CA I has migrated to the neutral peptide region in CA I HIR-1 (Fig. 4B). Since the normal (yellow stained) peptide appears to have a charge of -1 , its migration ratio of 0.4 relative to aspartic acid indicates that it has a molecular weight of about 500 (Offord, 1966).

\section{Amino Acid Sequence}

As shown and described in Fig. 5, the amino acid sequences of the normal and altered tryptic peptides were: 
A

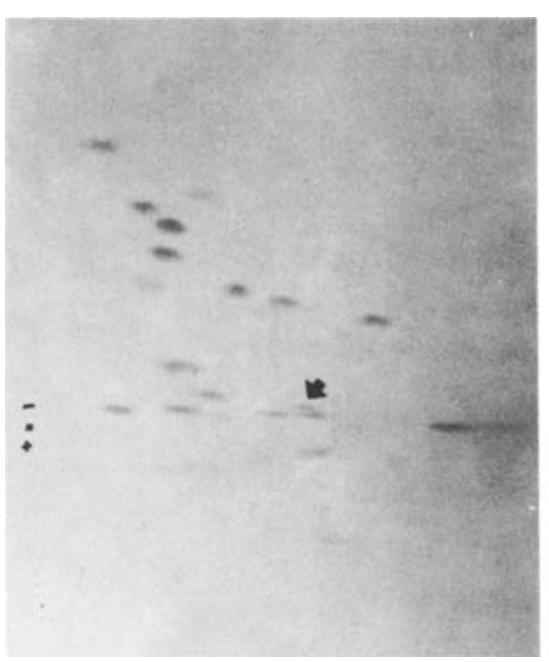

CA I

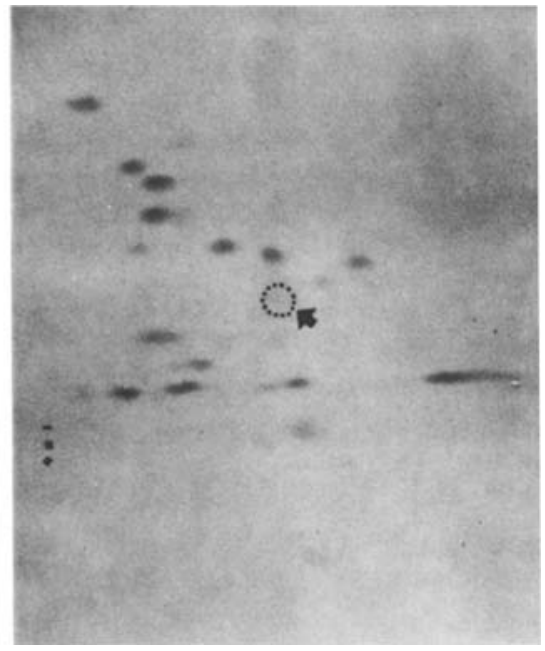

CA I HIR-1

B

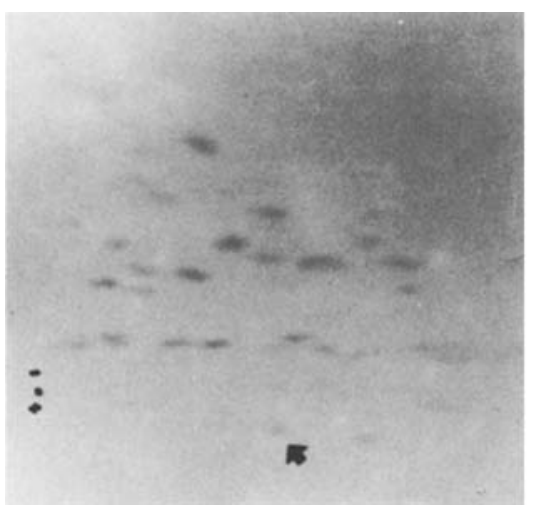

CA I

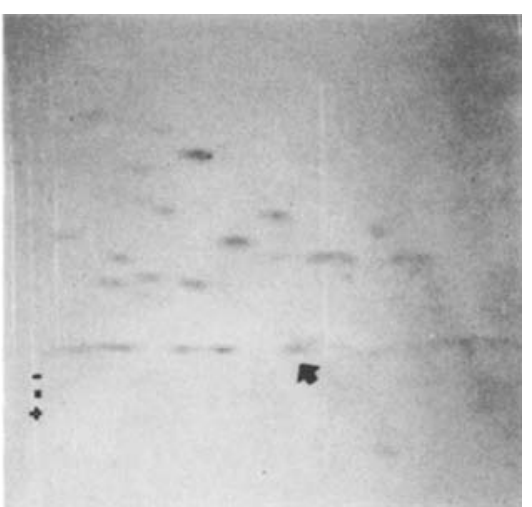

CA I HIR-1

Fig. 4. Tryptic (A) and chymotryptic (B) peptide patterns of normal CA I and CA I HIR-1. Arrows indicate normal and variant peptides. Electrophoresis carried out at $p \mathrm{H} \mathrm{6.4.}$ 

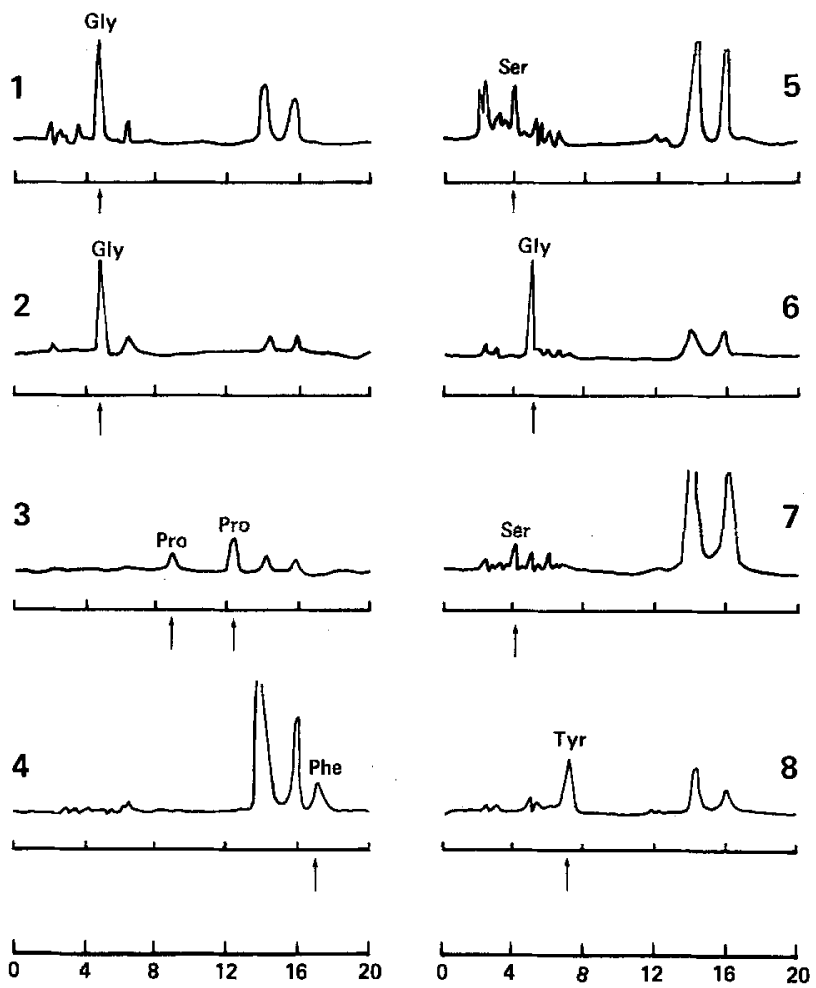

ELUTION TIME (min.)

Fig. 5. Amino acid sequence steps of the variant tryptic peptide (residues 81-89) from CA I HIR-1 analyzed by HPLC elution of PTH-amino acids. The sequence was the same for these residues from normal CA I with the exception of Asp (eluting time: $2.4 \mathrm{~min}$ ) at step 6. Typical elution times (min) of standard PTH-amino acids: Asp (2.5), Glu (3.2), Asn (3.6), Gln (3.8), Ser (4.0), Thr (4.6), Gly (5.1), Ala (6.4), Tyr (6.9), $\Delta$ Thr (8.2), Pro-1 (9.0), Val (11.6), Pro-2 (12.3), Trp (14.9), Phe (16.9), Lys/Ile (17.8), Leu (19.6). Peaks at $\sim 14$ and 16 min probably degradation products of reagents. See text for procedural details.

\section{$81 \quad 86 \quad 89$ \\ Normal CA I Gly-Gly-Pro-Phe-Ser-Asp-Ser(Tyr,Arg) \\ CA I HIR-1 Gly-Gly-Pro-Phe-Ser-Gly-Ser-Tyr-Arg}

Examination of the human CA I sequence shows that these peptides represent residues 81 to 89 (Andersson et al., 1972; Lin and Deutsch, 1973), and that the aspartyl residue at position 86 in normal CA $I$ has been replaced by a glycyl residue in CA I HIR-1 (Fig. 5).

The molecular weight of the variant tryptic peptide is 926 , which agrees 
well with the value of 1000 estimated from its electrophoretic mobility. The normal and altered chymotryptic peptides are most likely residues $85-88$, Ser-Asp-Ser-Tyr (normal) and Ser-Gly-Ser-Tyr (CA I HIR-1). The normal peptide has a molecular weight of 480 , which agrees well with the value of 500 estimated from its electrophoretic mobility.

\section{Thermal Stability}

The results of the thermal denaturation studies are shown in Fig. 6. As can be seen, all of the variant enzymes are less stable than normal CA I. On the basis of showing the same altered tryptic and chymotryptic peptides, it is assumed that the CA I HIR- 1 variant in the individual from Nagasaki has the same substitution (86 Asp $\rightarrow$ Gly) as the other examples of CA I HIR-1; however, it is of interest that this sample of the variant from Nagasaki appears to be more stable than the other seven variant samples, as its heat denaturation curve lies midway between CA I and the CA I HIR-1 samples. It is therefore possible that the variant from Nagasaki may represent an additional alteration in its primary structure (e.g., neutral amino acid substitution), which confers greater stability; however, a careful reexamination of this variant must be undertaken before this can be clarified.

\section{Enzyme Activities}

The specific esterase ( $p$-nitrophenyl acetate) activity of each of the eight purified variant samples appeared to be within normal limits. The mean $\pm S D$

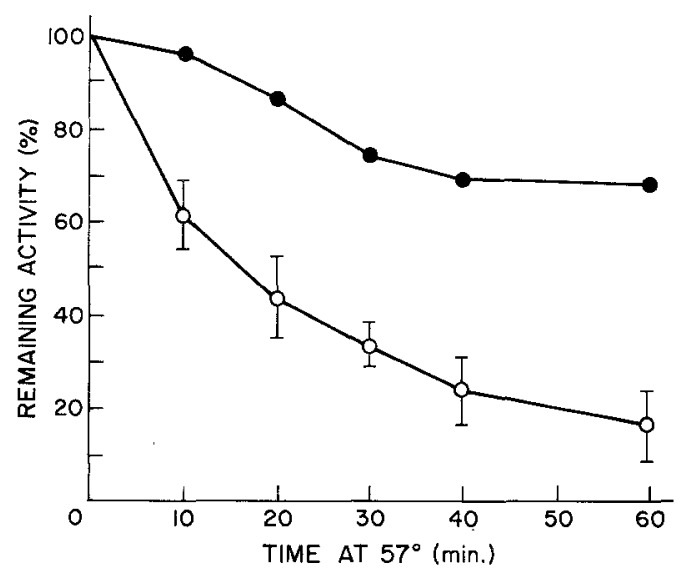

Fig. 6. Heat stability of normal CA I and CA I HIR-1. The enzymes were assayed for residual $p$-nitrophenyl acetate activity. Esterase activity of normal CA I (๑); means and ranges for the seven samples of CA I HIR-1 from Hiroshima (O). See text for details of procedure. 
value for the esterase activities of the eight variant samples was $19.6 \pm 3.2$ $\mu$ mol $p$-nitrophenol formed $/ \mathrm{min} / \mu$ mole CA I at $25^{\circ} \mathrm{C}$ (single normal control value, 20.4).

\section{Difference Spectra}

As can be seen in Fig. 7, the difference spectra for CA I and CA I HIR-1 are very similar. This finding suggests that the amino acid substitution does not affect the conformation of the active site residues. In an earlier report, the difference spectra of CA I and CA I HIR-1 were reported to be somewhat different (Tanis et al., 1976).

\section{DISCUSSION}

In addition to determining the amino acid replacement in one purified sample of CA I HIR-1, it was of interest to determine whether the other six purified samples of CA I HIR-1 from Hiroshima and the one sample of CA I HIR-1 from Nagasaki represented the same variant allele. In all eight variant samples, not only did the tryptic peptides at both $p \mathrm{H} 6.4$ and $p \mathrm{H} 2.0$ show the same migration patterns, but the chymotryptic peptides also showed identical patterns. The fact that the isoelectric focusing pattern of the CA I HIR-1 variant from Nagasaki is identical to the one from Hiroshima, and both are uniquely different from CA I (see Fig. 3), further supports the idea that it also has the same amino acid substitution. However, the increased thermostability of the CA I HIR-1 from Nagasaki relative to the other CA I HIR-1

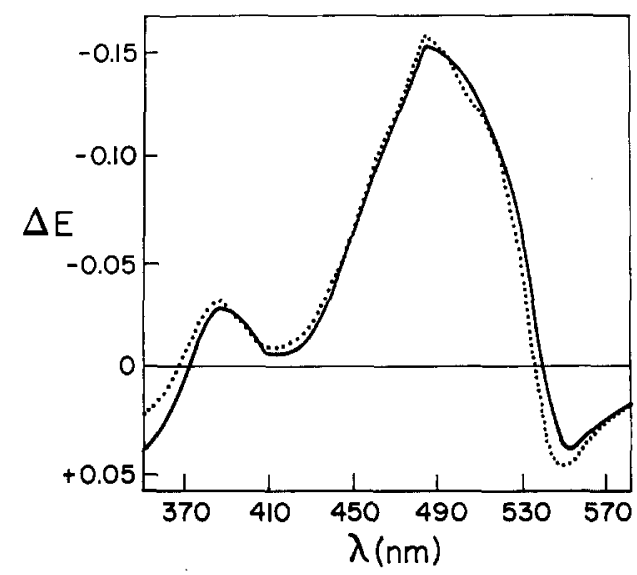

Fig. 7. Difference spectra for Neoprontosil complexes of normal CA I $(\ldots)$ and CA I HIR-1 $\left(-\left(-\right.\right.$ ) Conditions: $25^{\circ} \mathrm{C} ; 0.1 \mathrm{M}$ Hepes buffer, $p \mathrm{H}$ 7.5; enzyme concentrations, $20 \mu \mathrm{M}$. 
samples does raise the possibility that a second substitution undetected by peptide mapping or isoelectric focusing might be present. This individual should clearly be resampled and carefully reexamined.

The aspartic acid residue at position 86 in human CA I is located on the outside of the molecule (Notstrand et al., 1975) and does not appear to be part of any secondary structure. This residue is aspartic acid in the CA I isozymes of chimpanzee, orangutan, rhesus macaque, and rabbit (cf. Tashian, 1977; Contel et al., 1981; and unpublished data). However, it is of interest that this residue is glycine in the low activity CA I of turtle (Tashian et al., 1981), in the CA II isozymes of human, rhesus, sheep, ox, and rabbit (cf. Tashian, 1977, and unpublished data) and in the muscle CA III isozymes of human and gorilla (Hewett-Emmett and Tashian, 1979, and unpublished data). These findings suggest that glycine is the ancestral residue at position 86 , and that the substitution of glycine for aspartic acid at this position in CA I HIR-1 represents a back mutation.

Four other variants of human CA I have been demonstrated (by direct comparison) to have identical electrophoretic mobilities to CA I HIR-1 at $p \mathrm{H}$ 8.15 and 8.6 (cf. Tashian et al., 1980 c). These are CA I Hull (225 Gln $\rightarrow$ Arg/Lys), CA I Portsmouth (255 Thr $\rightarrow$ Arg), CA I Guam (253 Gly $\rightarrow$ Arg), and CA I Montreal-2. These variants represent the most cathodally migrating variants of CA I with a charge of +1 that have been examined so far.

Two other electrophoretic variants of CA I, CA I Nagasaki (76 Arg $\rightarrow$ Gln) (Goriki et al., 1979) and CA I Hiroshima-2 (Goriki et al., 1980), and one variant of CA II, CA II Hiroshima (K. Goriki, personal communication) have been discovered in the same survey of the Hiroshima and Nagasaki populations in which the CA I Hiroshima-1 variants were found.

\section{ACKNOWLEDGMENTS}

We are grateful to Dr. J. V. Neel for his interest and helpfulness throughout this work. We also thank Dr. Howard B. Hamilton, Dr. Chiyoko Satho, and Dr. Kazuaki Goriki of the Radiation Effects Research Foundation, Hiroshima, for their help in screening for the CA I variants, Dr. Shotaro Neriishi for collecting the blood sample from Nagasaki, and members of Medical Sociology, including Isamu Yasoda, Radiation Effects Research Foundation, for contacting the individuals with the CA I variants. We also acknowledge $\mathrm{R}$. Scott Decker for his help with the isoelectric focusing experiment.

\section{REFERENCES}

Andersson, B., Nyman, P. O., and Strid, L. (1972). Amino acid sequence of human erythrocyte CA B. Biochem. Biophys. Res. Commun. 48:670. 
Armstrong, J. McD., Myers, D. V., Verpoorte, J. A., and Edsall, J. T. (1966). Purification and properties of human erythrocyte carbonic anhydrases. J. Biol. Chem. 241:5137.

Carter, M. J. (1972). Carbonic anhydrase: isoenzymes, properties, distribution, and functional significance. Biol. Rev. 47:465.

Carter, N., Jeffery, S., Shiels, A., Edwards, Y., Tipler, T., and Hopkinson, D. A. (1979). Characterization of human carbonic anhydrase III from skeletal muscle. Biochem. Genet. 17:837.

Contel, E. P. B., Hewett-Emmett, D., Stroup, S. K., and Tashian, R. E. (1981). Amino acid sequence of chimpanzee carbonic anhydrase I (CAI): evolutionary implications for the origins of humans and great apes. Isozyme Bull. 14:44.

Goriki, K., Tashian, R. E., Stroup, S. K., Yu, Y.-S. L., Henriksson, D. M. (1979). Chemical characterization of a new Japanese variant of carbonic anhydrase I, CA I Nagasaki 1 (76 Arg $\rightarrow$ Gln). Biochem. Genet. 17:449.

Goriki, K., Kawamoto, S., and Tashian, R. E. (1980). The new variant carbonic anhydrases in the Japanese: CA I Nagasaki-1 (76 Arg $\rightarrow$ Gln) and CA I Hiroshima-2. Hemoglobin 4:653.

Heilmann, J., Barrollier, J., and Watzke, E. (1957). Beitrag zur Aminosäurebestimmung auf Papierchromatogrammen. Physiol. Chem. 309:219.

Hewett-Emmett, D., and Tashian, R. E. (1979). Human skeletal muscle carbonic anhydrase (CA III): purification, structure and evolution (abstract). Am. J. Human Genet. 31:50A.

Hopkinson, D. A., Coppock, J. S., Mühlemann, M. F., and Edwards, Y. H. (1974). The detection and differentiation of the products of the human carbonic anhydrase loci, CA I and CA II, using fluorogenic substrates. Ann. Human Genet. 38:155.

Kannan, K. K., Notstrand, B., Fridborg, K., Lovgren, S., Ohlsson, A., and Petef, M. (1975). Crystal structure of human erythrocyte carbonic anhydrase B. Three-dimensional structure at a nominal $2.2 \AA$ resolution. Proc. Natl. Acad. Sci. U.S.A. 72:51.

King, J., and Laemmli, U. K. (1971). Polypeptides of the tail fibres of bacteriophage T4. J. Mol. Biol. 62:465.

Laemmli, U. K., and Favre, M. (1973). Maturation of the head of bacteriophage T4. I. DNA packaging events. J. Mol. Biol. 80:575.

Lin, K. T. D., and Deutsch, H. F. (1973). Human carbonic anhydrases. XI. The complete primary structure of carbonic anhydrase B. J. Biol. Chem. 248:1885.

Lindskog, S., Henderson, L. E., Kannan, K. K., Liljas, A., Nyman, P. O. and Strandberg, B. (1971). Carbonic anhydrase. In Boyer, P. D. (ed.), The Enzymes, Vol. V, Academic Press, New York, pp. 587-665.

Notstrand, B., Vaara, I., and Kannan, K. K. (1975). Structural relationship of human erythrocyte carbonic anhydrase isozymes B and C. In Markert, C. L. (ed.), Isozymes, Vol. 1, Academic Press, New York, pp. 575-599.

Offord, R. E. (1966). Electrophoretic mobilities of peptides on paper and their use in the determination of amine groups. Nature 211:591.

Osborne, W. R. A., and Tashian, R. E. (1975). An improved method for the purification of carbonic anhydrase isozymes by affinity chromatography. Anal. Biochem. 64:297.

Pocker, Y., and Sarkenan, S. (1978). Carbonic anhydrase: structure, catalytic versatility and inhibition. Adv. Enzymol. 47:149.

Tanis, R. J., Osborne, W. R. A., Ueda, N., and Tashian, R. E. (1976). Biochemical characterization of the carbonic anhydrase variant, CA Ih Hiroshima. Human Genet. 34:29.

Tashian, R. E. (1977). Evolution and regulation of the carbonic anhydrase isozymes. In Rattazzi, M. C., Scandalios, J. G., and Whitt, G. S. (eds.), Isozymes: Current Topics in Biological and Medical Research, Vol. 2, Alan R. Liss, New York, pp. 21-62.

Tashian, R. E., and Carter, N. D. (1976). Biochemical genetics of carbonic anhydrase. In Harris, H., and Hirschhorn, K. (eds.), Advances in Human Genetics, Vol. 7, Plenum Press, New York, pp. 1-56.

Tashian, R. E., Hewett-Emmett, D., and Goodman, M. (1980a). Evolutionary diversity in the structure and activity of carbonic anhydrase. In Peeters, H. (ed.), Protides of the Biological Fluids, Colloquium 28, Pergamon Press, Oxford, U.K., pp. 153-156.

Tashian, R. E., Hewett-Emmett, D., Stroup, S. K., Goodman, M., and Yu, Y.-S. L. (1980b). 
Evolution of structure and function in the carbonic anhydrase isozymes of mammals. In Bauer, C., Gros, G., and Bartels, H. (eds.), Biophysics and Physiology of Carbon Dioxide, Springer-Verlag, New York, pp. 165-176.

Tashian, R. E., Kendall, A. G., and Carter, N. D. (1980c). Inherited variants of human red cell carbonic anhydrases. Hemoglobin 4:635.

Tashian, R. E., Stroup, S. K., and Hall, G. E. (1981). Primary sequence of turtle low-activity red cell carbonic anhydrase: homology with mammalian low-activity CA I isozymes. Federation Proc. 40:1677.

Tashian, R. E., Riggs, S. K., and Yu, Y.-S. L. (1966). Characterization of a mutant human erythrocyte carbonic anhydrase: carbonic anhydrase Ic Guam. The amino acid substitution and carboxylesterase and hydratase activities. Arch. Biochem. Biophys. 117:320.

Ueda, N. (1974). New Japanese variant of human erythrocyte carbonic anhydrase. Jpn. J. Human Genet. 19:161.

Ueda, N., Satoh, C., Tanis, R. J., Ferrell, R. E., Kishimoto, S., Neel, J. V., Hamilton, H. D., and Baba, K. (1977). The frequency in Japanese of genetic variants of 22 proteins II. Carbonic anhydrase I and II, lactate dehydrogenase, malate dehydrogenase, nucleoside phospholylase, triose phosphatase isomerase, haemoglobin $\mathrm{A}$ and haemoglobin $\mathrm{A}_{2}$. Ann. Human Genet. 41:43.

Zimmerman, C. L., Appella, E., and Pisano, J. J. (1977). Rapid analysis of amino acid phenylthiohydantoins by high-performance liquid chromatography. Anal. Biochem. 77:569. 